\title{
STUDI PEMANFAATAN ZEOLIT UNTUK PENGOLAHAN BIODIESEL DAN BIOETANOL
}

\author{
STUDY OF ZEOLITE UTILIZATION \\ FOR BIODIESEL AND BIOETHANOL PROCESSING
}

\author{
Anna Dwi Rachmawati ${ }^{*}$ Khairun Nisa, Novy Pralisa Putri \\ Program Studi Teknik Kimia, Universitas Mulawarman, Samarinda \\ Jl. Sambaliung No. 9 Kampus Gunung Kelua, Samarinda, Kalimantan Timur
}

Alamat Korespondensi: annadwr16@gmail.com

\begin{abstract}
Abstrak
Dalam kajian ini akan diberikan tinjauan terintegrasi mengenai potensi pemanfaatan keunggulan sifat zeolit yang ditinjau dari bidang energi yaitu dalam pembuatan biodiesel dan bioetanol. Tujuan dalam kajian mengenai topik ini yaitu untuk menyajikan perkembangan terbaru mengenai peran zeolit dalam pengolahan bidiesel dan bioetanol. Zeolit merupakan mineral industri multi guna karena memiliki sifat-sifat fisika dan kimia yang unik yaitu sebagai penyerap, penukar ion, penyaring molekul dan sebagai katalisator. Karena banyaknya keunggulan sifat zeolit maka dilakukan pengembangan pemanfaatan zeolit secara luas yaitu pada bidang energi. Dari kajian yang telah dilakukan dapat diketahui bahwa penggunaan zeolit di bidang energi dapat digunakan sebagai katalis dalam pembuatan bahan bakar minyak (BBM). Dalam pembuatan biodiesel dari minyak jelantah digunakan zeolit jenis 13-X, 5A, FM-8, dan AW-300. Pembuatan biodiesel dari minyak jarak pagar dengan katalis zeolit jenis MCM-48. Katalis Zeolit-X dimanfaatkan dalam pembuatan biodiesel dari minyak mustard. Pembuatan biodiesel dari minyak kedelai dengan katalis zeolit jenis Na-X dan Zeolit ETS10. Katalis zeolit $\mathrm{KOH} /$ Zeolit $\mathrm{Na}-\mathrm{Y}$ dimanfaatkan dalam pembuatan biodiesel dari kelapa sawit. Modifikasi katalis $\beta$ - zeolit dimanfaatkan dalam pembuatan biodiesel dari minyak Tamanu (Calophyllum inophyllum). Zeolit jenis HZSM-5 yang berasal dari negara USA, Rusia, Arabian, Spanyol and Cina dapat dimanfaatkan dalam proses dehidrasi bioetanol, transformasi bioetanol menjadi hidrokarbon, dan produksi petrokimia terbarukan dari biomassa dan plastik.
\end{abstract}

Kata Kunci: zeolit, biodiesel, bioetanol

\begin{abstract}
In this study will be given an integrated review of the potential utilization of zeolite properties superiority in the field of energy in the manufacture of biodiesel and bioethanol. The purpose of this review to presents recent developments in utilization of zeolite in the energy sector while focuses on manufactured in the processing of bidiesel and bioethanol. Zeolite are multi-use mineral industry, because it has unique physical and chemical properties, such as absorber, ion exchangers, molecular sieves and catalyst. Because of many advantages of zeolite properties, scientist made the development of utilization of zeolite widely as energy sector. From the studies that have been done can be seen that the use of zeolite in the energy sector can be used as a catalyst in the manufacture of fuel oil. In the manufacture of biodiesel used zeolite type-X zeolite types 13, 5A, FM-8, and AW-300. Production biodiesel from jatropha oil with type zeolite catalysts MCM-48. X-zeolite catalyst utilized in production biodiesel from mustard oil. Making biodiesel from soybean oil are used zeolite catalyst type zeolite Na-X and ETS-10. The zeolite catalyst $\mathrm{KOH} /$ zeolite $\mathrm{Na}-\mathrm{Y}$ utilized in biodiesel production from palm oil. Modification of the catalyst - zeolite utilized in biodiesel production from Tamanu oil (Calophyllum inophyllum). Zeolite can be used in dehydration of bioethanol, transformation of bioethanol into hydrocarbons, bioethanol conversion Into hydrocarbon, and production of renewable petrochemical by co-feeding of biomass with plastics. That type of zeolite is zeolite HZSM-5 from USA, Rusia, Arabian, Spanyol and Cina.
\end{abstract}

Keywords: zeolite, biodiesel, bioethanol 


\section{PENDAHULUAN}

Permasalahan energi yang dihadapi Indonesia sekarang ini adalah kebutuhan energi nasional yang besar dan meningkat setiap tahun sementara cadangan dan produksi bahan bakar minyak (BBM) semakin terbatas, sehingga sejak beberapa tahun terakhir Indonesia telah berubah dari eksportir menjadi importir minyak mentah (Kasim dkk, 2011). Namun produksi dan pemakaian bahan bakar fosil yang terus-menerus berdampak negatif terhadap lingkungan. Produksi dan pemanfaatan bahan bakar fosil secara terusmenerus mengakibatkan kerusakan lingkungan yeng serius seperti kerusakan spesies akuatik karena tumpahan minyak, pemanasan global akibat emisi gas rumah kaca seperti $\mathrm{CO}_{2}$ dan $\mathrm{CH}_{4}$, pengurangan konsekuen dalam lahan pertanian dan berkurangnya air tawar untuk kebutuhan rumah tangga dan aplikasi industri (Galadima dan Muraza, 2015).

Kelangkaan dan kenaikan harga bahan bakar fosil serta polusi dan dampak penggunaan bahan bakar fosil terhadap lingkungan, mengakibatan diperlukannya pengembangan energi alternatif terbarukan dan bersih sebagai pengganti bahan bakar fosil (Serra dan Chica, 2011). Minyak solar merupakan salah satu fraksi minyak bumi yang banyak digunakan sebagai bahan bakar di industri maupun di transportasi. Saat ini muncul berbagai usaha untuk mencari energi alternatif pengganti minyak solar (Aziz dkk, 2012).

Pengganti energi berbasis fosil yang berpotensi di Indonesia seperti biogas juga telah dikembangkan menyatakan bahwa Indonesia memiliki potensi sumber daya peternakan yang dipergunakan selain untuk pemenuhan kebutuhan pangan, juga berpotensi sebagai sumber energi dengan menggunakan teknologi biogas (Wahono, 2008). Tumbuh keprihatinan lingkungan dan peraturan perundang-undangan yang ketat, dibuat kominitas ilmiah untuk mengembangkan katalis yang dapat memungkinkan penggunaannya dalam aplikasi besar skala industri dan membantu dalam mereda polusi. Zeolit, aluminosilikat anggota keluarga dari bahan mikro dasar yang padat dan dapat bertindak sebagai pendukung untuk logam alkali dan oksida logam (Volli dkk, 2015).

Diantara bahan anorganik yang digunakan dalam bidang ini, zeolit merupakan bahan yang baik untuk membran polimer, karena membantu untuk mempertahankan hidrasi yang cocok dari kondisi operasi membran sel bahan bakar, dan sifat mekanik yang ditingkatkan. Zeolit adalah kelas aluminosilikat kristal, yang membentuk kerangka tetrahedral $\mathrm{SiO}_{2}$ dan $\mathrm{AlO}_{4}$ dan mengandung penukar kation pada kerangka ektrsa untuk menjaga netralitas listrik. Zeolit alami dan sintesis diketahui banyak diaplikasikan dalam proses industri termasuk dalam pemisahan kimia dan pemurnian, produksi kimia dan konversi bahan bakar, pengurangan dan remediasi polusi (Devrim dkk, 2015).

Zeolit merupakan sekelompok mineral aluminosilikat terhidrasi dengan saluran dan rongga tertentu. Ruang kosong dalam rongga zeolit yang berisi kation dapat dipertukarkan dengan kation lain. Sifat ini dikenal dengan kapasitas tukar kation. Kemampuan zeolit sebagai penukar ion sebanding dengan konsentrasi ion $\mathrm{Al}^{3+}$ dalam zeolit (Nikmah dkk, 2009). Berdasarkan uraian diatas zeolit merupakan material yang berhasil diterapkan dalam berbagai bidang yang luas dan mampu memberikan nilai tambah. Dalam kajian ini akan diberikan tinjauan terintegrasi mengenai potensi pemanfaatan keunggulan sifat zeolit yang ditinjau dari bidang energi yaitu dalam pembuatan biodiesel dan bioetanol.

\section{Penggunaan Zeolit dalam Pembuatan Biodiesel}

Heterogen basa transesterifikasi triglesirida telah muncul sebagai alternatif untuk sistem homogen konvensional karena selektivitas yang tinggi, pemisahan yang mudah, dan masalah pembuangan yang tidak banyak. Karena keprihatinan terhadap lingkungan dan peraturan ketat perundang-undangan yang dibuat oleh komunitas ilmiah untuk membuat katalis yang memungkinkan diaplikasikan dalam skala besar industri dan membantu dalam mengurangi polusi.

Dalam penelitian yang dilakukan oleh Volli, dkk (2015) diaplikasikan empat jenis zeolit dengan flyash yang dimanfaatkan untuk sintesis katalis heterogen dalam transesterifikasi. Empat jenis zeolit tersebut yaitu UZ-X, CZ-X, AZ-X, dan Zeolit A. Semua jenis zeolit tersebut akan disintesis dari fusi alkali diikuti dengan perlakuan hidrotermal dari flyash batubara sebagai kondisi sintesis dais umber material. Diketahui fase tunggal dan sangat kristal, zeolit $\mathrm{X}$ dan $\mathrm{A}$ disintesis dari kondisi flyash diperoleh pada flyash / rasio $\mathrm{NaOH}(1: 1,2)$, suhu fusi $550{ }^{\circ} \mathrm{C}$, waktu fusi $1 \mathrm{jam}$, suhu hidrotermal $110{ }^{\circ} \mathrm{C}$, dan waktu hidrotermal 12 jam. 
Tabel 1. Penggunaan Zeolit sebagai Katalis dalam Produksi Biodiesel

\begin{tabular}{|c|c|c|c|c|c|c|c|}
\hline No. & Bahan Baku & $\begin{array}{c}\text { Jenis } \\
\text { Minyak }\end{array}$ & $\begin{array}{l}\text { Waktu } \\
\text { (Jam) }\end{array}$ & $\begin{array}{c}\text { Suhu } \\
\left({ }^{\circ} \mathrm{C}\right)\end{array}$ & $\begin{array}{c}\text { Rasio } \\
\text { Katalisator } \\
(w t \%)\end{array}$ & $\begin{array}{c}\text { Rasio } \\
\text { Molar } \\
\text { Minyak } \\
(\mathrm{wt} \%) \\
\end{array}$ & $\begin{array}{l}\text { Konversi } \\
(\%)\end{array}$ \\
\hline 1. & Flyash Zeolit-X & Mustar & 7 & 65 & 5 & $12: 1$ & 84,6 \\
\hline 2. & $\begin{array}{l}\text { 12-Tungstophosporic } \\
\text { acid (TPA), MCM-48 }\end{array}$ & Jarak Pagar & 16 & 65 & 6 & $8: 1$ & 93 \\
\hline 3. & $\begin{array}{c}\text { Katalis nano Strontium, } \\
\text { ZSM-5 }\end{array}$ & Bunga Matahari & 4 & 60 & 3 & $9: 1$ & 87,7 \\
\hline 4. & $\mathrm{KOH}$ / Zeolit $\mathrm{Na}-\mathrm{Y}$ & Kelapa sawit & 7 & 60 & 15 & $\begin{array}{l}\text { Tidak } \\
\text { ada }\end{array}$ & 92.1 \\
\hline 5. & $\begin{array}{l}\text { Asam fosfat, modifikasi } \\
\qquad \beta \text { - zeolit }\end{array}$ & $\begin{array}{c}\text { Tamanu } \\
\text { (Calophyllum } \\
\text { inophyllum) }\end{array}$ & 1 & 60 & 1 & $9: 1$ & 93 \\
\hline
\end{tabular}

Sumber:

1) Volli, dkk (2015), 2) Signh, dkk (2014), 3) Feyzi, dkk (2014), 4) Intarapong, dkk (2011),

5) SathyaSelvabala, dkk (2011)

Tabel 2. Penggunaan Zeolit dalam Produksi Bioetanol

\begin{tabular}{|c|c|c|c|c|}
\hline No. & Zeolit & Negara & Proses & Keterangan \\
\hline 1 & HZSM-5 & USA & $\begin{array}{l}\text { Dehidrasi } \\
\text { bioetanol }\end{array}$ & $\begin{array}{l}\mathrm{T}=773 \mathrm{~K} \\
\mathrm{P}=50 \mathrm{MPa} \\
\mathrm{Si} / \mathrm{Al}=52 \\
\text { Ukuran Kristal }=0,5-1,5 \mu \mathrm{m} \\
\text { Selektifitas etilen }=27 \%\end{array}$ \\
\hline 2 & HZSM-5 & USA & $\begin{array}{l}\text { Dehidrasi } \\
\text { bioetanol }\end{array}$ & $\begin{array}{l}\mathrm{T}=773 \mathrm{~K} \\
\mathrm{P}=60 \mathrm{MPa} \\
\mathrm{Si} / \mathrm{Al}=70 \\
\text { Ukuran Kristal }=700-1400 \mu \mathrm{m} \\
\text { Selektifitas propilen }=29 \%\end{array}$ \\
\hline 3 & HZSM-5 & Saudi Arabia & $\begin{array}{l}\text { Konversi } \\
\text { bioetanol menjadi } \\
\text { bahan bakar }\end{array}$ & $\begin{array}{l}\mathrm{T}=500 \mathrm{~K} \\
\mathrm{P}=1 \text { atm } \\
\text { Kandungan } \mathrm{Ar}=9 \% \\
\text { Selektifitas } \mathrm{C}_{1}-\mathrm{C}_{4}=74 \% \\
\text { Selektifitas } \mathrm{C}_{5} \text { dan } \mathrm{BTX}=15 \%\end{array}$ \\
\hline 4 & HZSM-5 & Saudi Arabia & $\begin{array}{l}\text { Konversi } \\
\text { bioetanol menjadi } \\
\text { bahan bakar }\end{array}$ & $\begin{array}{l}T=450 \mathrm{~K} \\
\mathrm{P}=1 \mathrm{~atm} \\
\text { Selektifitas } \mathrm{C}_{1}-\mathrm{C}_{4}=40 \% \\
\text { Selektifitas } \mathrm{C}_{5} \text { dan BTX }=60 \%\end{array}$ \\
\hline 5 & HZSM-5 & Cina & $\begin{array}{l}\text { Proses pembuatan } \\
\text { hidrokarbon dari } \\
\text { biomasa }\end{array}$ & $\begin{array}{l}\text { Bahan baku }=\text { Selulosa } \\
\mathrm{T}=550{ }^{0} \mathrm{C} \\
\text { Yield aromatik }=32,9 \% \\
\text { Yield olefin }=2,68 \% \\
\text { Yield petrokimia }=35,6 \% \\
\text { Yield alkana }=2,06 \% \\
\text { Yield } \mathrm{CO}=23 \% \\
\text { Yield } \mathrm{CO}_{2}=5,96 \%\end{array}$ \\
\hline 6 & HZSM-5 & Rusia & $\begin{array}{l}\text { Konversi } \\
\text { bioetanol menjadi } \\
\text { hidrokarbon }\end{array}$ & $\begin{array}{l}\mathrm{T}=400{ }^{\circ} \mathrm{C} \\
\mathrm{P}=3 \text { atm } \\
\mathrm{Si} / \mathrm{Al}=30 \\
\text { Yield hidrokarbon cair }=26,20 \%\end{array}$ \\
\hline
\end{tabular}




\begin{tabular}{|c|c|c|c|c|}
\hline No. & Zeolit & Negara & Proses & Keterangan \\
\hline 7 & HZSM-5 & Rusia & $\begin{array}{l}\text { Konversi } \\
\text { bioetanol menjadi } \\
\text { hidrokarbon }\end{array}$ & $\begin{array}{l}\mathrm{T}=400{ }^{\circ} \mathrm{C} \\
\mathrm{P}=3 \mathrm{~atm} \\
\mathrm{Si} / \mathrm{Al}=50\end{array}$ \\
\hline 8 & HZSM-5 & Rusia & $\begin{array}{l}\text { Konversi } \\
\text { bioetanol menjadi } \\
\text { hidrokarbon }\end{array}$ & $\begin{array}{l}\mathrm{T}=400{ }^{\circ} \mathrm{C} \\
\mathrm{P}=3 \mathrm{~atm} \\
\mathrm{Si} / \mathrm{Al}=90\end{array}$ \\
\hline 9 & HZSM-5 & Spanyol & $\begin{array}{l}\text { Konversi } \\
\text { bioetanol menjadi } \\
\text { hidrokarbon }\end{array}$ & $\begin{array}{l}\mathrm{T}=375-425^{\circ} \mathrm{C} \\
\mathrm{SiO}_{2} / \mathrm{Al}_{2} \mathrm{O}_{3}=30 \\
\text { Volume mesopori }=0,12 \mathrm{~cm}^{3} / \mathrm{g} \\
\text { Ukuran pori }=5,3 \AA\end{array}$ \\
\hline 10 & HZSM-5 & Brazil & $\begin{array}{l}\text { Konversi } \\
\text { bioetanol menjadi } \\
\text { hidrokarbon }\end{array}$ & $\begin{array}{l}\text { Yield olefin }=55 \% \\
\mathrm{~T}=500{ }^{0} \mathrm{C} \\
\mathrm{P}=0,12 \mathrm{~atm} \\
\mathrm{Sio} 2 / \mathrm{Al}_{2} \mathrm{O}_{3}=28 \\
\text { Volume mikropori }=0,165 \mathrm{~cm}^{3} / \mathrm{g} \\
\text { Volume mesopori }=0,021 \mathrm{~cm}^{3} / \mathrm{g} \\
\text { Total keasaman }=1629 \mu \mathrm{mol} \mathrm{NH}_{3} / \mathrm{g} \\
\text { Selektifitas etilen }>29 \%\end{array}$ \\
\hline
\end{tabular}

Sumber:

1-2. X. Li, dkk (2016), 3-4. Galadima, dkk (2015), 5-6 X. Li, dkk (2014), 7-9 Sousa, dkk (2014), 10 - 14 Gayubo, dkk (2010)

Untuk nilai kapasitas tukar kation (KTK) pada sintesis zeolit jenis UZ-X dan AZ-X yaitu sebesar 168,2 meq/100g dan 325,7 meq/100g, ketika masing-masing dilakukan penukaran ion dengan kalium KTK meningkat menjadi UZ-KX dan AZ-KX sebesar 276,5 meq/100g dan 380,6 meq/100g. Dari penelitian tersebut diketahui zeolit A memiliki nilai kapasitas tukar kation yang tertinggi yaitu sebesar $536,3 \mathrm{meq} / 100 \mathrm{~g}$. Aktivitas katalitik sintesis zeolit ( AZ-KX) untuk transesterifikasi minyak mustard diketahui konversi maksimum dari $84,6 \%$ diperoleh pada $5 \%$ berat katalis pemuatan dengan rasio molar minyak 12:1 metanol, waktu reaksi 7 jam pada suhu $65{ }^{\circ} \mathrm{C}$. Biodiesel yang diperoleh diketahui memiliki nilai kalori $37,5 \mathrm{MJ} / \mathrm{Kg}$. Berdasarkan Tabel 1, dapat disimpulkan bahwa penggunaan flyash dapat menjadi alternatif yang menjanjikan dalam pengembangan sintesis katalis heterogen untuk trasesterifikasi.

Dalam penelitian lainnya yang menggunakan zeolit untuk produksi biodiesel juga telah dilakukan oleh Signh, dkk (2014) yang mensintesis 12-Tungstophosphoric Acid (TPA) dan bahan molekul mesopori (Mobile Komposisi Materi/MCM-48), karakterisasi dan penggunaannya sebagai katalis heterogen dieksplorasi untuk produksi biodiesel melalui esterifikasi asam oleat dengan metanol. Dilakukan pengujian terhadap pengaruh berbagai parameter reaksi seperti rasio molar, massa katalis, waktu reaksi dan suhu reaksi dievaluasi.
Diketahui katalis MCM-48 menunjukkan aktivitas yang sangat baik terhadap produksi biodiesel, yaitu 95\% konversi diperoleh dengan rasio molar minyak jarak pagar (Jatropha) $8: 1$, pada suhu $65^{\circ} \mathrm{C}$, waktu $16 \mathrm{jam}$, dan rasio katalis 6 wt\%. Studi kinetik mengungkapkan bahwa esterifikasi asam oleat mengikuti hukum tingkat urutan pertama dengan energi aktivasi 40,3 kJ mol A1.

Katalis didaur ulang setelah regenerasi sederhana tanpa kerugian yang signifikan dalam konversi. Aktivitas katalitik yang sangat baik atas katalis ini diperpanjang untuk reaksi transesterifikasi untuk produksi biodiesel dari minyak jelantah dan minyak jarak pagar (jatropha), sebagai bahan baku dengan harga yang murah. Sifat fisika kimia dari biodiesel yang dihasilkan menunjukkan bahwa diperoleh sifat terkandung sebanding dengan spesifikasi ASTM. Dari paparan diatas menunjukkan bahwa MCM-48 sangat disarankan dalam produksi biodiesel dari minyak jarak pagar (jatropha).

SathyaSelvabala, dkk (2011) juga telah melakukan penelitian dalam pembuatan biodiesel. Penelitian tersebut diaplikasikan proses dua langkah yang dikembangkan untuk memproduksi biodiesel dari minyak nyamplung / Tamanu (Calophyllum inophyllum). Dilakukan dengan perlakuan awal asam b-zeolit yang dimodifikasi dengan asam fosfat dalam proses esterifikasi katalisator katalis yang sebelumnya telah didahului dengan transesterifikasi yang 
dilakukan dengan menggunakan katalis alkali biasa kalium hidroksida $(\mathrm{KOH})$. Tujuan penelitian ini adalah untuk mengetahui hubungan antara suhu reaksi, waktu reaksi dan metanol untuk rasio molar minyak dalam tahap praperawatan. Metode Central Composite Design (CCD) dan Respon Metodologi Permukaan (RSM) digunakan untuk menentukan kondisi operasi terbaik untuk pra- perlakuan biodiesel yang dihasilkan oleh proses ini dengan melakukan penngujian pada sifat bahan bakarnya. Dari penelitian ini dihasilkan biodiesel dari minyak nyamplung dengan konversi $93 \%$ pada suhu $60{ }^{\circ} \mathrm{C}$, rasio molar minyak 9:1, rasio katalisator $1 \mathrm{wt} \%$ dan waktu selama 1 jam. Intarapong, dkk (2011) juga telah melakukan penelitian pembuatan biodiesel dari minyak kelapa sawit menggunakan katalis zeolit. Dalam penelitian tersebut menggunakan katalis $\mathrm{KOH} / \mathrm{NaY}$ menggunakan reaktor packed bed. Diketahui $15 \%$ berat katalis K / NaY zeolit menunjukkan aktivitas katalitik yang sangat baik dan hasil konversi mencapai $92,18 \%$ pada suhu $60{ }^{\circ} \mathrm{C}$ dan waktu reaksi selama 7 jam. Hasil konversi yang tinggi membuat katalis $\mathrm{K} / \mathrm{NaY}$ zeolit cukup menjanjikan untuk memproduksi biodiesel dari minyak kelapa sawit dalam skala besar.

Dalam penelitian yang telah dilakukan oleh Feyzi, dkk (2014) dengan menginvestigasi aktivitas nanocatalyst strontium yang didukung dengan Zeolit ZSM-5 pada transesterifikasi minyak bunga matahari untuk produksi biodiesel FAME (fatty acids methyl ester). Katalis tersebut disiapkan melalui metode impregnasi basah. Efek dari berbagai Sr / ZSM- 5, rasio massa Ba-Sr / ZSM-5 dan kondisi kalsinasi pada aktivitas katalitik telah diselidiki. Aktivitas yBa - xSr / ZSM-5 (dimana $\mathrm{x}=6 \%$ berat strontium berdasarkan berat ZSM-5 dan y $=4$ wt. $\% \mathrm{Ba}$ berdasarkan pada berat Sr) dipelajari pada kondisi operasional yang berbeda seperti rasio molar metanol / minyak, massa rasio katalis terhadap minyak, waktu reaksi dan suhu reaksi. Diketahui bahwa katalis yang mengandung YBa $\mathrm{xSr} / \mathrm{ZSM}-5$ (dimana $\mathrm{x}=6$ wt.\% Strontium berdasarkan berat ZSM-5 dan $\mathrm{y}=4$ wt. $\%$ Barium berdasarkan Berat strontium) merupakan katalis optimal untuk produksi biodiesel. Hasilnya menunjukkan bahwa kondisi operasional terbaik yaitu pada metanol $/$ minyak $=9 / 1$ dengan suhu $60{ }^{\circ} \mathrm{C}$ dan pengadukan mekanik $500 \mathrm{rpm}$ selama 180 menit. Hal tersebut merupakan hasil biodiesel FAME maksimum sebesar 87,7\% yang dicapai dengan menggunakan katalis optimal. Karakterisasi sampel katalis dilakukan dengan spektroskopi infra merah transformasi Fourier (FTIR), pemindaian elektron mikroskop (SEM), difraksi sinar-X (XRD), dan metode pengukuran adsorpsi-desorpsi $\mathrm{N}_{2}$. Berbagai jenis zeolit yang digunakan dalam produksi biodiesel yang berasal dari berbagai jenis minyak dapat dilihat pada Tabel 1.

\section{Penggunaan Zeolit dalam Pembuatan Bioetanol}

Dalam rangka memenuhi tuntutan energi dunia saat ini, sumber energi yang kurang dimaanfaatkan seperti bahan bakar minyak pirolisis (PFO), light cycle oil (LCO), dan minyak kovensional (aspal, residu vakum) perlu dipertimbangkan sebagai sumber potensial karbon untuk nilai tambah produksi bahan kimia dan bahan bakar transportasi (Upare dkk, 2016). PFO adalah cairan organik coklat gelap yang terdiri dari hidrokarbon poli-aromatik $\left(\mathrm{PHA}_{\mathrm{S}}\right)$ seperti naphthalene derivative. Senyawa tersebut dapat dirubah menjadi mononuklear aromatik dan hidrokarbon non-aromatik dalam proses pengilangan. Meskipun demikian, karena bahan pengotor yang sedikit, kandungan aromatik yang lebih tinggi dan rendahnya biaya, menjadikan PFO sebagai sumber potensial untuk bahan bakar transportasi seperi BTX (benzena, toluen dan xilena) (Upare dkk, 2016).

Selain dengan pemanfaatan PFO, sumber energi alternatif lain yang dapat digunakan yaitu etanol yang dapat digunakan sebagai bahan tambahan dalam bahan bakar transportasi. Galadima dan Muraza (2015) menyatakan bahwa etanol merupakan hidrokarbon yang memiliki sifat mirip dengan bahan bakar fosil dan dapat digunakan secara langsung atau dicampur dengan bahan bakar tanpa kesulitan dan membutuhkan konfigurasi ulang mesin.

Dibandingkan dengan bahan bakar lainnya, bioetanol memiliki serangkaian keuntungan, karena lebih mudah dalam proses penyimpanan, penanganan dan transportasi dengan cara yang aman karena toksisitas dan volatilitas yang lebih rendah. Selain itu, dari sudut pandang lingkungan, bioetanol menghasilkan keuntungan penting karena merupakan logam-bebas dan tidak melepaskan gas kontaminan (SO x, NOx dan lain-lain) (Serra dan Chica, 2011).

Bioetanol diperkirakan akan menjadi bahan bakar yang berharga atau memiliki nilai jual yang baik. Pada tahun 1980-an di Brazil, mobil-mobil telah dirancang untuk dapat berjalan dengan menggunakan etanol sebagai bahan bakar. Produksi etanol Brazil pada tahun 1975 
berkisar 320 juta liter dan meningkat menjadi 12 miliar liter di tahun 1986. Pada tahun 1994 peraturan perundang-undangan mewajibkan penggunaan $22 \%$ alkohol anhydrous untuk ditambahkan ke dalam gasoline sehingga menyebabkan produksinya menjadi 14 miliar liter dimana sepertiga bagiannya adalah alcohol anhydrous. Mereka juga menambahkan bahwa di Amerika Serikat, etanol digunakan sebagai penambah bilangan oktan di dalam gasoline seperti halnya methyl tert-butyl ether (MTBE) yang dipilih sebagai pengganti tetraethyl lead (TEL) yang telah dilarang penggunaannya di dalam gasoline. Pelarangan penggunaan timbal diikutu dengan kegiatan udara bersih (Clean Air $A c t$ ) yang menetapkan penggunaan oksigenat sehingga menyebabkan gasoline (terutama sekali fraksi aromatiknya) dapat terbakar lebih bersih (Khaidir dkk, 2009).

Saat ini etanol dicampur dengan bensin hingga rasio $10 \%$ dengan tujuan untuk meningkatkan bilangan oktan dan mengurangi emisi polutan seperti $\mathrm{CO}_{2}, \mathrm{NO}_{\mathrm{x}}$ dan hidrokarbon poliaromatik. Di Amerika Serikat, lebih dari 95\% mobil yang menggunakan bensin yang dicampur dengan 10\% bahan bakar grade etanol. Demikian pula Badan Perlindungan Lingkungan (EPA) mengizinkan pencampuran $15 \%$ etanol dengan $85 \%$ bensin untuk digunakan dalam kendaraan baru (yaitu model 2001 dan model setelahnya) (Galadima dan Muraza, 2015).

Selain digunakan sebagai bahan campuran bensin, etanol juga dapat digunakan sebagai sumber energi lainnya. Bioetanol adalah salah satu produk turunan biomassa yang dapat dikonversi menjadi hidrokarbon seperti olefin ringan, LPG, biofuel, dan beberapa petrokimia penting lainnya seperti aromatik $\mathrm{C}_{6}-\mathrm{C}_{8}$. Selain hidrokarbon, bio-ethanol juga dapat menghasilkan beberapa oxygenates seperti 2pentanone dan metil ester dengan bantuan katalis (Choopun dan Jitnarka, 2016).

Dehidrasi etanol menjadi hidrokarbon dapat berlangsung dalam dua jalur umum yaitu bio-etanol dapat dikonversi menjadi etilen oleh dehidrasi antar molekul pada suhu tinggi, dan dehidrasi dehidrasi intramolekul pada suhu rendah lebih dominan untuk mengkonversi etanol menjadi dietil eter yang dapat dikonversi menjadi etilen dan olefin $\mathrm{C}_{4}$ pada suhu tinggi. Selektifitas produk yang diperoleh dari dehidrasi etanol dapat diatur oleh promotor dan kuantitas yang digunakan, struktur fisik dan sifat kimia bahan pendukung, serta interaksi natara bahn pendukung dan promotor. Etanol dapat dikonversi menjadi etilena, hidrokarbon $\mathrm{C}^{3+}$, dietil eter dan air. Hidrokarbon $\mathrm{C}^{3+}$ diklasifikasikan menjadi tiga fraksi yaitu $\mathrm{C}_{3}-\mathrm{C}_{4}$, $\mathrm{C}_{5}-\mathrm{C}_{11}$ (produk dominan), dan $\mathrm{C}^{12+}$ (Choopun dan Jitnarka, 2016).

Berdasarkan penelitian yang dilakukan Chica dan Sayas (2009) tentang steam reforming bioethanol dengan menggunakan zeolit ITQ-2 dan promotor Ni dan $\mathrm{CO}$, didapatkan hasil bahwa dengan menggunakan promotor Co dan zeolit ITQ-2 dapat mengkonversi etanol hingga $70 \%$. Sedangkan dengan menggunakan promotor $\mathrm{Ni}$ dan katalis ITQ-2 dapat mengkonversi etanol lebih banyak yaitu $76.8 \%$ pada suhu $900 \mathrm{~K}$ dan dengan kandungan karbon paling sedikit yaitu sekitar 3.1\%.

Berdasarkan penelitian yang dilakukan oleh Serra dan Chica (2011) tentang pengaruh struktur kristal zeolit ITQ-18 pada proses steam reforming bioethanol, diketahui bahwa dengan menggunakan promotor Co dan katalis zeolit ITQ-18, mampu mengkonversi bioetanol hingga 98.3\% dengan selektifitas terhadap $\mathrm{CH}_{4}$ sebesar $5.7 \%$, CO sebesar $3.1 \%, \mathrm{CO}_{2}$ sebesar $19.5 \%, \mathrm{H}_{2}$ sebesar $71.2 \%, \mathrm{C}_{2} \mathrm{H}_{4} 0.1 \%$ dan $\mathrm{CH}_{3} \mathrm{CHO}$ sebesar $0.4 \%$.

Selain menggunakan zeolit ITQ, pada proses konversi etanol menjadi bahan kimia lain seperti hidrokarbon seperti olefin, aromatik, alkana dan bahan kimia lain juga dapat menggunakan zeolit HZSM-5. Berdasarkan penelitian Gayubo, dkk (2010) tentang stabilitas hidrotermal katalis HZSM-5 yang dimodifikasi dengan $\mathrm{Ni}$ untuk merubah bioetanol menjadi hidrokarbon, diketahui bahwa penggunaan zeolit HZSM-5 dengan rasio $\mathrm{SiO}_{2}$ dan $\mathrm{Al}_{2} \mathrm{O}_{3}$ sebesar 30 dengan perbandingan pada suhu $270 \mathrm{~K}$ dan 280 $\mathrm{K}$ terjadi reaksi dehidrasi etanol menjadi etena. Pada suhu reaksi yang lebih tinggi terjadi pembentukan olefin sekitar $55 \%$ pada kisaran suhu $375-425{ }^{\circ} \mathrm{C}$.

Berdasarkan penelitian yang dilakukan oleh Li, dkk (2016) tentang olefin ringan dari sumber terbaharukan, diketahui bahwa dengan menggunakan katalis HZSM-5 pada rasio perbandingan $\mathrm{Si}$ dan $\mathrm{Al}_{2}$ yang berbeda-beda yaitu 52, 74,76, dan 184 pada suhu $773 \mathrm{~K}$ tekanan 50 MPa dan waktu kontak $0.0025,0.0125,0.02$ dan $0.04 \mathrm{~g} /(\mathrm{mL} / \mathrm{menit})$, diperoleh bahwa selektifitas katalis terhadap propilen mengalami penurunan seiring dengan seamakin lawa waktu kontak katalis dengan etanol pada perbandingan $\mathrm{Si}$ dan $\mathrm{Al}_{2}$ 52, 74 dan 76. Berbeda dengan selektifitas propilen pada rasio $\mathrm{Si}$ dan $\mathrm{Al}_{2}$ sebesar 184 yang mengalami kenaikan seiring dengan lamanya waktu kontak katalis. Pada percobaan tersebut diperoleh bahwa selektifitas optimum terhadap 
propilen terjadi pada rasio $\mathrm{Si}$ dan $\mathrm{Al}_{2}$ sebesar 52 pada waktu kontak $0.0025 \mathrm{~g} /(\mathrm{mL} /$ menit) yaitu sekitar 27\%. Pada rasio perbandingan antara $\mathrm{Si}$ dan $\mathrm{Al}_{2}$ sebesar 80 pada tekanan $50 \mathrm{MPa}$ dan dengan variasi waktu kontak katalis, suhu operasi, dan perbandingan promotor $\mathrm{P}$ yang ditambahkan, diketahui bahwa semakin tinggi suhu operasi, maka semakin besar selektifitas propilen, bebeda dengan apabila rasio promotor $\mathrm{P}$ yang ditambahkan maka semakin semakin kecil selektifitas propilen yang dihasilkan. Pada variasi waktu kontak katalis terjadi kenaikan selektifitas ketika waktu kontak antara 0.0025-0.01 $\mathrm{g} /(\mathrm{mL} / \mathrm{menit})$ yang kemudian mengalami penurunan pada waktu kontak 0.01875 $\mathrm{g} /(\mathrm{mL} / \mathrm{menit})$. Sehingga pada penelitian tersebut diketahui bahwa pada rasio perbandingan Si dan $\mathrm{Al}_{2}$ sebesar 80 diperoleh selektifitas terbesar terhadap propilen yaitu $32 \%$ pada rasio promotor P/Al sebesar 0.5 , suhu $823 \mathrm{~K}$ dan waktu kontak katalis sebesar $0.01 \mathrm{~g} /(\mathrm{mL} / \mathrm{menit})$.

Selain dengan menggunakan bahan baku etanol, hidrokarbon juga dapat diperoleh dengan menggunakan biomasa dan plastik dengan bantuan zeolit HZSM-5. Berdasarkan penelitian yang dilakukan Li, dkk (2014), diketahui bahwa pada suhu operasi $550{ }^{0} \mathrm{C}$ dan dengan perbandingan katalis dan reaktan sebesar 15 diperoleh bahwa yield armoatik sebesar 32.9\%, olefin sebesar 2.68\%, alkane sebesar $2.06 \%$, karbon monoksida sebesar 23\%, karbon dioksida sebesar $5.96 \%$, petrokimia sebesar $35.6 \%$ dan padatan (coke dan char) sebesar 34\% dengan bahan baku selulosa. Pada penggunaan lignin sebagai bahan baku diperoleh yield aromatik sebesar $7.84 \%$, olefin sebesar $1.71 \%$, alkane sebesar $2.06 \%$, karbon monoksida sebesar $2.05 \%$, karbon dioksida sebesar $2.05 \%$, petrokimia sebesar $9.55 \%$ dan padatan (coke dan char) sebesar $64.7 \%$. Pada bahan baku kayu pinus diperoleh yield aromatik sebesar $28.5 \%$, olefin sebesar $3.09 \%$, alkane sebesar $2.49 \%$, karbon monoksida sebesar $15.1 \%$, karbon dioksida sebesar $3.16 \%$, petrokimia sebesar $31.6 \%$ dan padatan (coke dan char) sebesar 46.5\%. Pada penggunaan LDPE sebagai bahan baku diperoleh yield aromatik sebesar $23.8 \%$, olefin sebesar $12.7 \%$, alkane sebesar $55.1 \%$, petrokimia sebesar 41\% dan padatan (coke dan char) sebesar $6.74 \%$. Pada pengguanaan poli phinil sebagai bahan baku pembuatan hidrokarbon, diperoleh yield aromatik sebesar $35.4 \%$, olefin sebesar $13.9 \%$, alkane sebesar $48.9 \%$, petrokimia sebesar $49.3 \%$ dan padatan (coke dan char) sebesar 6.38\%. Sedangkan pada penggunaan poli stiren sebagai bahan baku diperoleh yield aromatik sebesar
$80.2 \%$, olefin sebesar $1.94 \%$, alkane sebesar $2.68 \%$, petrokimia sebesar $82.1 \%$ dan padatan (coke dan char) sebesar 10.2\%. Berbagai jenis zeolit yang dapat digunakan dalam pembuatan bioetanol dapat dilihat pada Tabel 2 .

\section{KESIMPULAN}

Berdasarkan kajian literatur ini diketahui bahwa dalam pengolahan biodiesel dapat dimanfaatkan beberapa jenis zeolit yang berasal dari berbagai macam minyak yaitu, jenis MCM48 dari minyak jarak pagar, zeolit-X dari minyak mustar, Na-X, ETS - 10, ZSM-5 dari minyak bunga matahari, zeolit $\mathrm{KOH} /$ zeolit $\mathrm{Na}-\mathrm{Y}$ dari minyak kelapa sawit, modifikasi $\beta$ - zeolit dari minyak Tamanu (Calophyllum inophyllum). Sedangkan dalam pengolahan bietanol dapat dimanfaatkan zeolit jenis HZSM-5.

\section{DAFTAR RUJUKAN}

Aziz, I., Nurbayati, S., \& Rahman, A. (2012). Penggunaan Zeolit Alam sebagai Katalis dalam Pembuatan Biodiesel. Valensi, 4(2), 511-514.

Chica, A., \& Sayas, S. (2009). Effective and Stable Bioethanol Steam Reforming Catalyst Based on Ni and Co Supported on All-Silica Delaminated ITQ-2 Zeolite. Scient Direct. 41-42.

Choopun, W., \& Jitnarka, S. (2016). Catalytic Activity and Stability of HZSM-5 Zeolite and Hierarchical Uniform Mesoporous MSU-S ${ }_{\text {zsm-5 }}$ Material During Bio-Ethanol Dehydration, Journal of Cleaner Production.

Feyzi, M., \& Khajavi, G. (2014). Investigation of biodiesel production using modified strontium nanocatalysts supported on the ZSM-5 zeolite. Industrial Crops and Products. 298-304.

Galadima, A., \& O. Muraza. (2015). Zeolite Catalysts in Upgrading of Bioethanol to Fuels Range Hydrocarbons: A Review. Science Direct. 1-2.

Gayubo, A. G., Alonso, A., Valle, B., Aguayo, A. T., Olazar, M., \& Bilbao, J. (2010). Hydrothermal Stability of HZSM-5 Catalysts Modified with $\mathrm{Ni}$ for the Transformation of Bioethanol Into Hydrocarbons. Scient Direct. 3368-3370.

Intarapong, P., Luengnaruemitchai, A., \& Jai-in, S. (2011). Transesterification of palm oil over $\mathrm{KOH} / \mathrm{NaY}$ zeolite in a packed-bed reactor. International Journal of 
Renewable Energy Research, IJRER : Thailand. 273-278.

Kasim, R., Setyaningsih, D., \& Haerudin, H. (), 2011) Esterifikasi Crude Palm Oil (CPO) Menggunakan Katalis Zeolit Alam Teraktifasi Asam pada Proses Pembuatan Biodiesel Melalui Metode Dua Tahap (Esterifikasi-Transesterifikasi). Agrointek. 1(5), 59-65.

Khaidir, Setyaningsih, D., \& Haerudin, H. (2009). Modifikasi Zeolit Alam Sebagai Material Molekular Sieve pada Proses Dehidrasi Bioetanol. Prosiding Seminar Nasional Zeolit VI. 488-503.

Nikmah, S. R. A., Widiastuti, N., \& Fansuri, H. (2009). Pengaruh Waktu dan Perbandingan Si/Al Terhadap Pembentukan Zeolit A dari Abu Dasar Bebas Karbon dari PT. IPMOMI dengan Metode Hidrotermal. Prosiding Seminar Nasional Zeolit VI : Bandung. 300-308.

SathyaSelvabala, V., Selvaraj, D.K., Kalimuthu, J., Periyaraman, P.M., \& Subramanian, S. (2011). Two-step biodiesel production from Calophyllumi-nophyllum oil: optimization of modified $\beta$-zeolite catalyzed pre-treatment. Bioresource Technology 102. 1066-1072.

Serra, J. F. D. C., \& Chica, A. (2011). Bioethanol steam reforming on Co/ITQ-18 catalyst: Effect of the Crystalline Structure of the Delaminated Zeolite ITQ-18. Scient Direct. 3362.

Singh, S., \& Patel, A. (2014). 12Tungstophosphoric acid supported on mesoporous molecular material: synthesis, characterization and performance in biodiesel production, Journal of Cleaner Production: India. 3-10.

Sousa, Z. S. B., Cesar, D. V., Henriques, C. A., \& Silva, V. T. D. (2014). Bioethanol Conversion Into Hydrocarbons on HZSM5 and HMCM-22 zeolites: Use of In Situ DRIFTS to Elucidate the Role of the Acidity and of the Pore Structure Over the Coke Formation and Product Distribution. Scient Direct. 4-5.

Upare, D. P., S. Park, M.S. Kim, Y. P. jeon, J. Kim, D. Lee, J. Lee, H. Chang, S. Choi, W. Choi, Y. K. Park, \& C. W. Lee. (2016). Selective Hydrocracking of Pyrolysis Fuel Oil Into Benzene, Toluene and Xylene Over Como/Beta Zeolite Catalyst. Science Direct. 356-360.

Volli, V., \& Purkait, M. K. (2015) Selective Preparation of Zeolite $X$ and A from Flyash and its use as Catalyst for Biodiesel Production. Journal of Hazardous Materials : India. 8-17.

X. Li, Kant, A., Y. He, Thakkar, H.V., Atanga, M.A., Razaei, F., Ludlow, D.K., \& Rownaghi, A.A. (2016). Light Olefins From Renewable Resources: Selective Catalytic dehydration of Bioethanol to Propylene Over Zeolite and Transitionmetal Oxide Catalysts. Scient Direct. 6-8.

X. Li, J. Li, G. Zhou, Y. Feng, Y. Wang, G. Yu, S. Deng, J. Huang, \& B. Wang. (2014). Enhancing the Production of Renewable Petrochemicals by Co-Feeding of Biomass with Plastics in Catalytic Fast Pyrolysis with ZSM-5 Zeolites. Scient Direct. 176. 